Portland State University

PDXScholar

7-1973

Possible Avian Influences in the Distribution of

Dwarf Mistletoe

Paul James Zilka

Portland State University

Follow this and additional works at: https://pdxscholar.library.pdx.edu/open_access_etds

Part of the Biology Commons, and the Poultry or Avian Science Commons Let us know how access to this document benefits you.

Recommended Citation

Zilka, Paul James, "Possible Avian Influences in the Distribution of Dwarf Mistletoe" (1973). Dissertations and Theses. Paper 1581.

https://doi.org/10.15760/etd.1580

This Thesis is brought to you for free and open access. It has been accepted for inclusion in Dissertations and Theses by an authorized administrator of PDXScholar. Please contact us if we can make this document more accessible: pdxscholar@pdx.edu. 
AN ABSTRACT OF THE THESIS OF Paul James Zilka for the Master of Science in Biology presented $26 \mathrm{July} 1973$.

Title: Possible Avian Influences in the Distribution of Dwarf Mistletoe.

APPROVED BY MEMBERS OF THE THESIS COMMITTEE :

Robert 0. Tinnin, Chairman

Richard Forbes

\section{Clyde Calvin}

The goal of this investigation was to determine the potential of birds as vectors for the movement of dwarf mistletoe seeds and the means by which such movement could occur. Birds would greatly speed the rate at which these parasites move horizontally or vertically through the forest. Five areas in oregon, heavily infected by six species of Arceuthobium were studied. Observations of avian behavior point to 13 species whose general behavior make them potential vectors in the distribution of these parasites. More specifically, the roosting and subsequent bathing behavior of most forest birds provides a very important means of potential seed transport. Additionally, an 
examination of nesting materials revealed that birds bring viable dwarf mistletoe seeds to infectible portions of host trees during the construction of their nests. Nesting, however, seems the least important of the vector mechanisms discussed. I observed no evidence of birds feeding on the seeds of dwarf mistletoe or of seeds being present in their droppings. The more probably means of seed transport is one of epizoochory. 


\title{
POSSIBLE AVIAN INFLUENCES IN THE DISTRIBUTION \\ OF DWARF MISTLETOE
}

\author{
by \\ PAUL JAMES ZILKA
}

\begin{abstract}
A thesis submitted in partial fulfillment of the requirements for the degree of
\end{abstract}

\author{
MASTER OF SCIENCE \\ in \\ BIOLOGY
}

\author{
Portland State University \\ 1973
}


TO THE OFFICE OF GRADUATE STUDIES AND RESEARCH:

The members of the Committee approve the thesis of

Paul James Zilka presented 26 July 1973.

Robert 0. Tinnin, Chairman

Richard Forbes

Clyde Calvin

Approved:

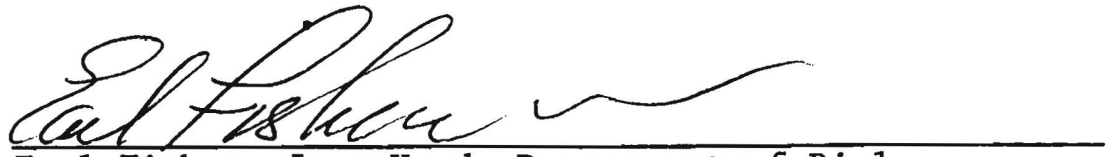

Earl Fisher, Jr., Head, Department of Biology

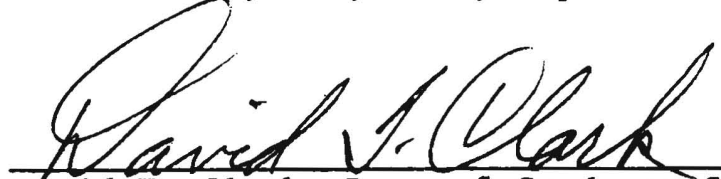

David T. Clark, Dean of Graduate Studies and Research 


\section{ACKNOWLEDGMENTS}

I wish to express my appreciation to Robert Tinnin for his guidance throughout this study, and especially to thank him and his family for their phenomenal patience and assistance. Additionally, I wish to note the august advice and interpretation given by Richard Forbes. Finally, I thank Carol Alosi for allowing me to use her dwarf mistletoe 1 ife cycle drawing. 
TABLE OF CONTENTS

PAGE

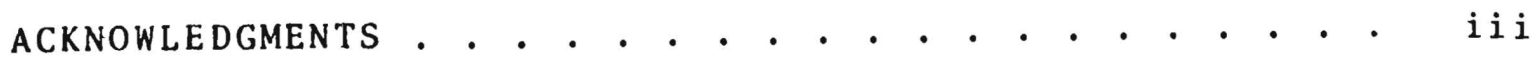

LIST OF TABLES . . . . . . . . . . . . . . . . . . . .

LIST OF FIGURES •

INTRODUCTION .

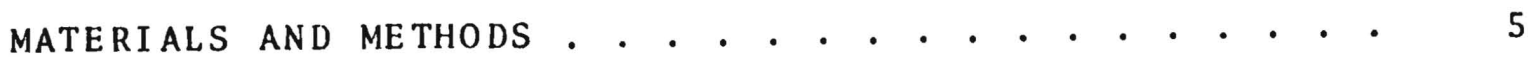

RESULTS AND DISCUSSION.

Field Observations During Period of

Seed Dispersal . . . . . . . . . . . . . . 11

Capture and Feeding Experiments . . . . . . . . . 28

Feeder Observations . . . . . . . . . . . . . . 30

Seeds on Nesting Materials. . . . . . . . . . . . 30

CONCLUSIONS . . . . . . . . . . . . . . . . . . . . . . . 40

Literature Cited. . . . . . . . . . . . . . . . . . 42 


\section{LIST OF TABLES}

TABLE

PAGE

I Host-Parasite Species Studied at Each Site.. .

I Species Commonly Found in Infected and

Infectible Trees. . . . . . . . . . . . 12

II Additional Species Observed in Infected

Trees . . . . . . . . . . . . . . . . 15

IV Birds of Oregon that Build Nests in Infectible

Portions of Host Trees. . . . . . . . . . 33 


\section{LIST OF FIGURES}

FIGURE

PAGE

1 Study Regions in oregon. . . . . . . . . . . . 7

2 Generalized Life Cycle of a Dwarf Mistletoe. . 10

3 Sequences of Perches Assumed by Steller's Jay. 10

4 Clark's Nutcracker Preening. . . . . . . . . . 21

5 Dwarf Mistletoe Seed on a Hemlock Near

My Feeder. . . . . . . . . . . . . . . . 31

6 Nesting Regions of Oregon. . . . . . . . . . . 37 


\section{INTRODUCT ION}

Dwarf mistletoe (Arceuthobium spp.: Loranthaceae) is indigenous to the northern hemisphere where it parasitically attacks many species of the Pinaceae and Cupressaceae. Considerable economic loss is realized in the coniferous forests of the New World due to these parasites (Hawksworth and Wiens, 1972). Stewart and Shea (1970) estimate that approximately $150 \times 10^{6}$ cubic feet of wood are lost annually to Arceuthobium in Oregon and Washington. Because of this large loss, many of the silvicultural practices for mistletoe infested regions are designed to limit the spread of this parasite. Clear cutting is considered the best currently available method of control although other methods of sanitation are also applied, particularly in areas where clear cutting is unfeasible. Since dwarf mistletoe is estimated to disperse through a stand at approximately $1.5 \mathrm{ft} . / \mathrm{yr}$. (Graham, 1967) by means of its explosive mechanism of seed dispersal, reinfection of sanitized stands should be relatively slow. Major errors in the application of this management principle would occur if infected whips (small trees) remain following sanitation such as by clear cutting (Smith, 1973), or if the mistletoe seeds disperse at a rate faster than estimated. 
Birds have long been recognized as real or potential spreaders of dwarf mistletoe seeds. The longest recorded avian transport of these seeds is that of Arceuthobium oxycedri on Juniperus brevifolia in the Azores, an infection 800 miles from the nearest known source (Ridley, 1930;

Hawksworth and Wiens, 1972). Additionally, the distribution of A. oxycedri in Europe, Asia and Africa is spotty and discontinuous and most likely due in part to birds (Ridley, 1930; Turri11, 1920; Gerber and Cotte, 1908).

A. tsugense also shows evidence of bird dispersal.

The parasite is found on Western Hemlock (Tsuga heterophyla) in the Pacific islands off the coast of liashington, British Columbia and Alaska (San Juan Islands, Queen Charlotte Is lands and the Alexander Archipelago). Most of these is lands were never connected to the mainland (Hawksworth and Wiens, 1972).

A. pusillum on Picea mariana and Picea glauca in North America also shows avian influence. It is indigenous to the Atlantic islands off the New England and Canadian coasts and to the islands of the Great Lakes along the United States Canadian border. Infections on most of these islands constitute a movement of seeds across considerable expanses of water (Ridley, 1930; Hawksworth and Wiens, 1972). Additionally, when the Canadian shield was wiped clean 20,000 years ago by the wisconsin glaciation (Pecora, Gerloch and Overstreet, 1970), A. pusillum was stripped from the area 
along with its host. With the recession of the ice and subsequent reforestation A. pusillum returned. Using the 1.5 ft./yr. lateral dispersal rate now recognized, one comes up with a dispersion of 30,000 feet, about six miles in $\angle 0,000$ years (Dyson, 1969). In fact, the parasite has moved northward at least 400 miles from the southern limits of the continuous ice sheet (Hawksworth and wiens, 1972), an average movement of more than $105 \mathrm{ft} . / \mathrm{yr}$.

A few authors recognize the potential for short range dispersal by birds. Opinions range from birds having no influence in the dispersal of dwarf mistletoe (Kuijt, 1969; Scharpf, 1964) to those who believe that birds are occasionally influential (Hawksworth and Wiens, 1972; von Schrenk, 1900; Meehan, 1882) to those who believe that birds have a regular and significant influence in the dispersal of these parasites (Ridley, 1930; van der Pijl, 1969; Gerber and Cotte, 1908; Zwinger, 1970; Weir, 1916a, 1916b; Turrill, 1920). Bird dispersal of dwarf mistletoe seed has as one of its most important implications the rapid reinfection of a stand cleared of the parasite. The goal of my investigation was two-fold. First, I wanted to determine which species of birds, because of their habits, have the greatest potential for spreading dwarf mistletoe seeds. Second, I wanted to determine the most important potential means of avian transport. The hope was that upon completion of my work, investigators in the field would know which species of birds 
to study and which of their habits to investigate in order to quantify the influence of birds in the spread of $d w a r f$ mist letoe. 


\section{MATERIALS AND METHODS}

This research was conducted from July, 1972 to May, 1973. The initial work involved locating areas of heavy infection. Three major areas and two supplemental areas were chosen. Priorities for the choices were: (1) stands heavily infected by species of Arceuthobium, (2) easy accessibility by automobile, (3) stands containing several host - parasite species combinations (Table I), and (4) relatively open areas so that bird observations were not seriously hampered.

Five areas of study were chosen: Site 1, Camp Sherman of the Deschutes National Forest; Site 2, the Maury Mountains in the Ochoco National Forest; Site 3, Summit Prairie in the Ochoco National Forest; Site 4, the Badger area of the Mt. Hood National Forest; Site 5, the Dodge district of the Mt. Hood National Forest (Figure 1). These regions are listed in order of the relative amounts of time spent in each.

The research was conducted in four parts: (1) observations of birds in the field during late summer and early fall, the season of dwarf mistletoe seed release; (2) capture of bird species most likely to feed on dwarf mistletoe seeds followed by attempts to feed them; (3) winter observation of birds at feeders supplied with dwarf mistletoe seeds, and (4) spring census of nesting birds and their nests 
TABLE I

\section{HOST-PARASITE SPECIES COMBINATION STUDIED AT EACH SITE}



$\begin{array}{lll}\text { Region } 2 & \frac{\text { Pinus ponderosa }}{\text { Pseudotsugamenzeisii }} & \frac{A}{A} \cdot \frac{\text { campylopodium }}{\text { Mouglasii }} \\ \text { Maury Mountains } & \frac{\text { Abies }}{\text { Abrandis }} \cdot \frac{\text { occidentalis }}{\text { garicis }}\end{array}$

\begin{tabular}{|c|c|c|c|c|}
\hline Region & 3 & $\frac{\text { Pinus }}{\text { Pseudc }}$ & $\frac{\text { ponderosa }}{\text { tsugamenzeisii }}$ & $\frac{A}{A} \cdot \frac{\text { campylopodium }}{\text { douglasii }}$ \\
\hline & & Larix & occidentalis & A. \\
\hline Summit & Prairie & Pinus & contorta & A. americanum \\
\hline
\end{tabular}

\begin{tabular}{|c|c|c|c|c|}
\hline \multirow{3}{*}{ Region } & 4 & Pseudo & tsuga menzeisii & A. douglasii \\
\hline & & Pinus & ponderosa & $\bar{A} \cdot \overline{c a m p y l o p o} d i u m$ \\
\hline & District & $\frac{\overline{\text { Larix }}}{\text { Abies }}$ & $\frac{\text { occidentalis }}{\text { grandis }}$ & $\overline{\bar{A}} \cdot \frac{\overline{\text { laricis }}}{\text { abietinum }}$ \\
\hline
\end{tabular}

Badger District Abies grandis

Region $5 \quad$ Tsuga heterophyla A. tsugense

Dodge District

1 Species listed were identified with the aid of treatments by Hawksworth and Wiens (1972).

2 My observations of birds were concentrated in regions 1,2 and 3 .

3 Arceuthobium species in each region are listed in order of frequency in the area. 


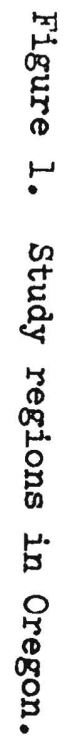

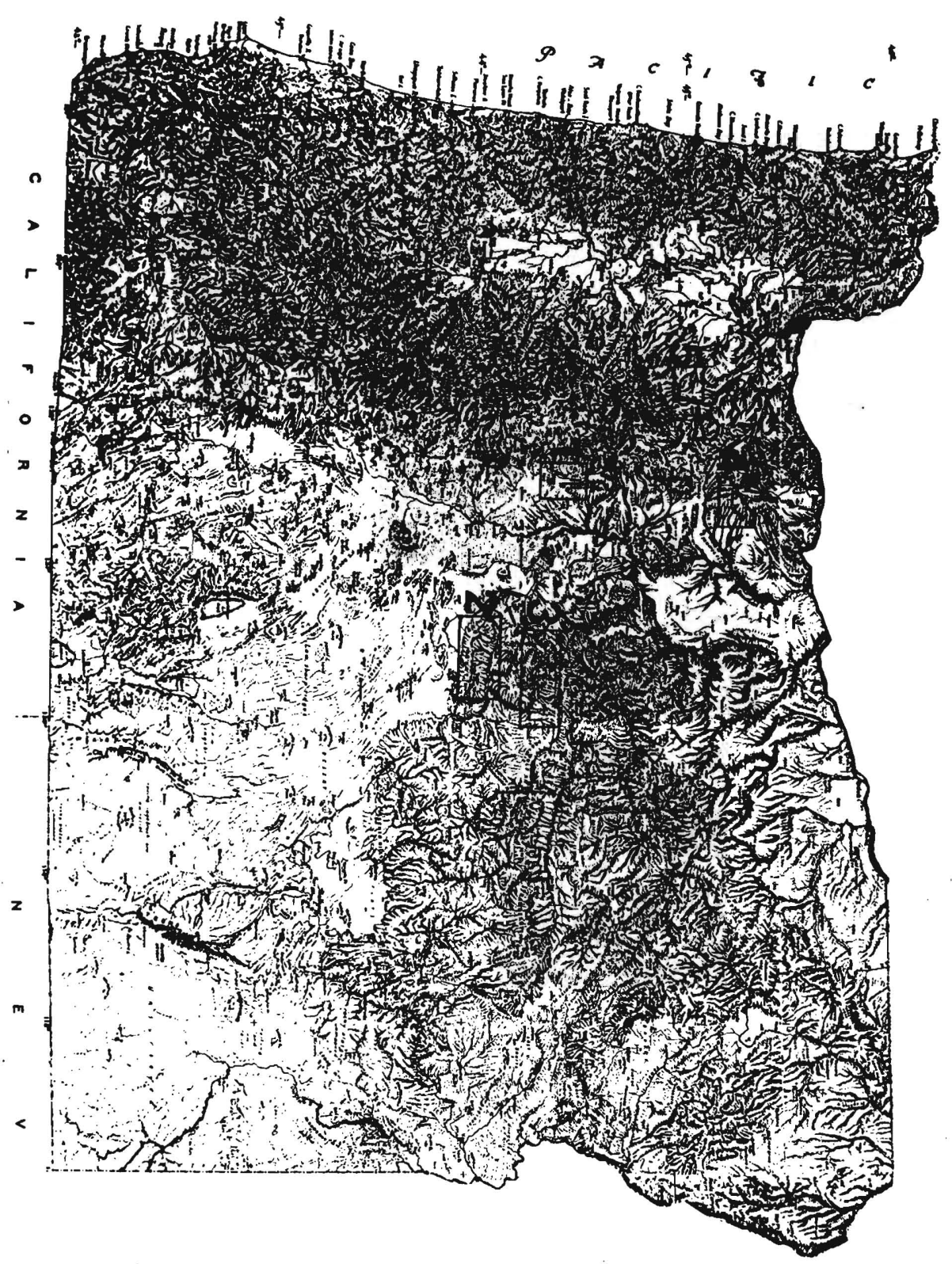


looking for dwarf mistletoe seeds which had been carried into infectible parts of trees on nesting materials.

Field observation of birds was accomplished with the aid of Bushnell binoculars $(7 \times 35)$ and a Bushnell spotting scope $(20-45 X)$. Identification of birds was facilitated by the use of reference books, (Robbins, Bruun and Zim, 1966; Peterson, 1941; Gabrielson and Jewett, 1940). Birds were captured with the use of a mist net (for smaller passerines) and Sherman Museum Traps (for corvids).

Observations of bird activity at feeders was accomplished at my home over the winter of 1972-73. A. campylopodium and $A$. tsugense seeds were supplied along with commercial bird seed and suet.

Pieces of nest materials were collected from the nests of the 1973 season's breeding populations. In addition, nesting materials were collected from Sites 1,2 and 5 during the spring and summer of 1973, some of which dated back to the 1972 breeding season. 


\section{RESULTS AND DISCUSSION}

My observations indicate that, for a bird to transport dwarf mistletoe seeds effectively, several important conditions must be met. First of all, the seed must become attached to the bird, or be carried by some other means. Mistletoe seeds are very sticky for various periods of time after being fired. This time period varies from minutes to a day or more depending upon such environmental factors as humidity, temperature and sun and wind exposure. In addition, after rewetting a dry seed, the hydrophobic seed coating (viscin) again becomes sticky (Hawksworth and Wiens, 1972). Any animal hit by a fired seed or that otherwise came in contact with a moist seed could become a vector in the distribution of dwarf mistletoe.

The life history of the parasite (Figure 2) places several important restrictions on the effective transport of dwarf mistletoe seeds: (1) all female seeds must land within one mile of a male infection to facilitate pollination and establish.seed production; (2) the seed must arrive in viable condition on a potential host; (3) the seed must be introduced to the younger portions of the host $1 \mathrm{imb}$ as it is incapable of regularly penetrating host tissues which are more than ten years old (Hawksworth, 1961). 


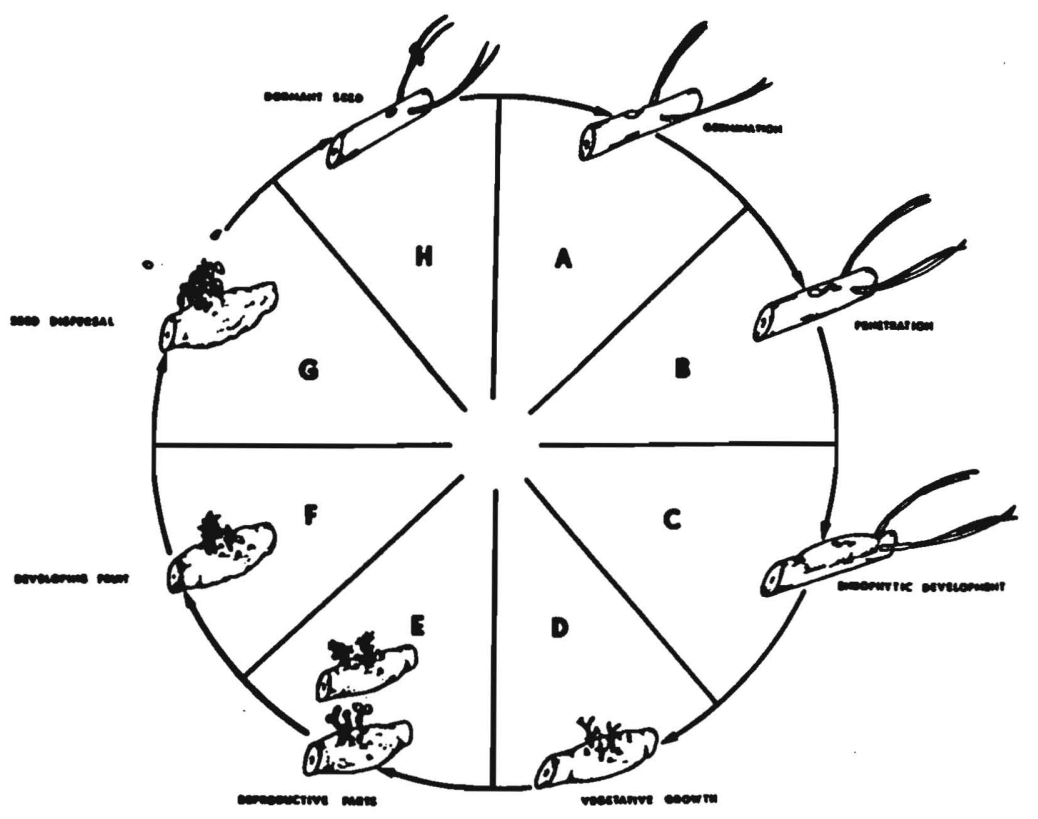

Figure 2. Generalized life cycle of a dwarf mistletoe.

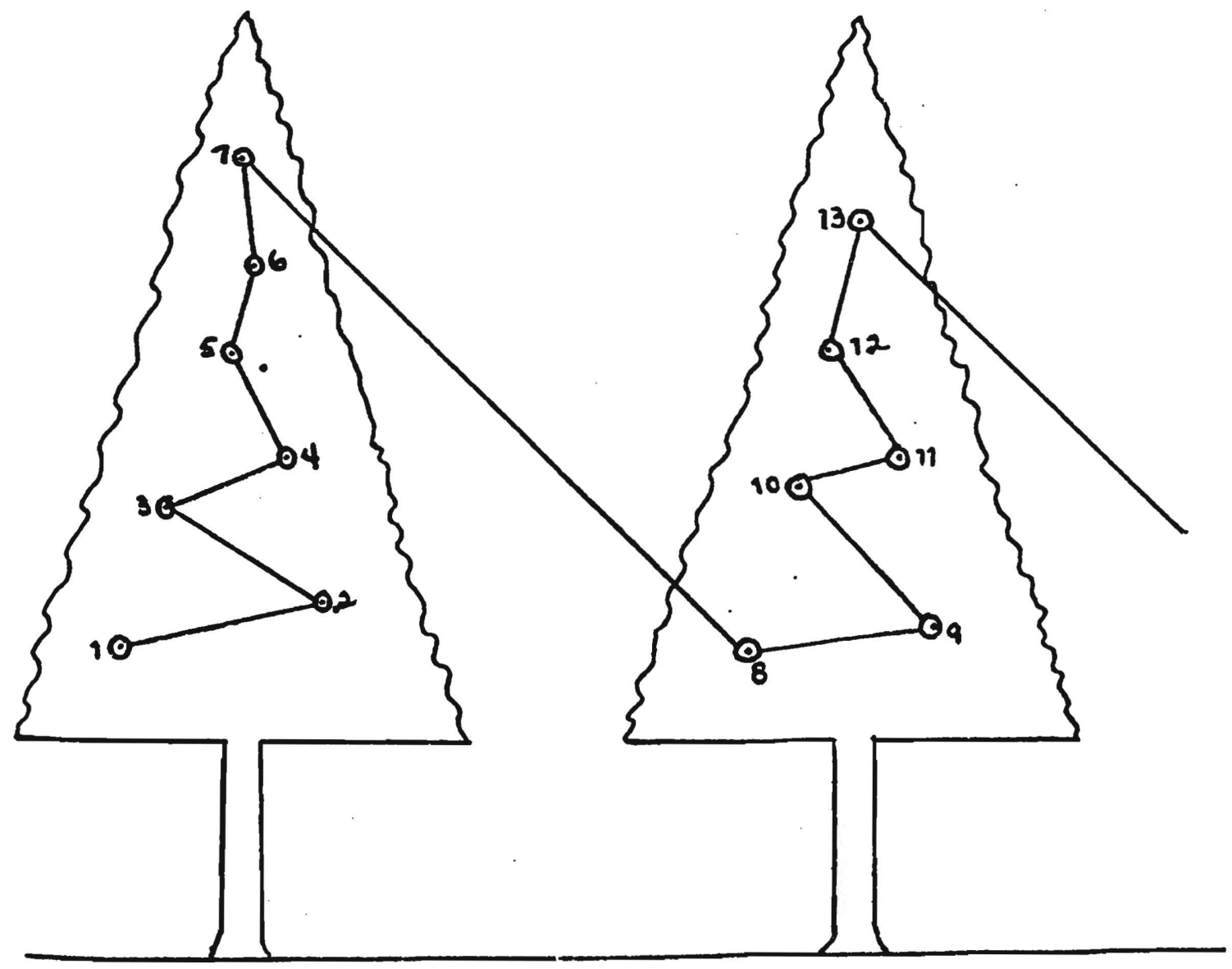

Figure 3. Sequences of perches assumed by Steller's Jay. 
Field Observations During Period of Seed Dispersal

A list of birds found in dwarf mistletoe infected trees during times of seed firing has been compiled ( $T a b l e s$ II and III). To each species on the list I have ascribed numbers which reflect the potential of a given species to act as a vector in the spread of dwarf mistletoe. Two basic components were evaluated to determine this potential. First, habitat priorities were determined by observing the amount of time individuals of a species spent in infected or infectible trees; these priorities are an expression of the potential of each species to pick up and transport mistletoe seeds relative to the total amount of time each species was observed. Second, frequencies of occurrence of each species were determined relative to the number of individuals of the most frequently observed species, the Red-Breasted Nuthatch. Each frequency is expressed as a whole number between 1 and 100 , with the Red-Breasted Nuthatch being 100. This frequency scale is accurate for the higher numbers but is inaccurate for values less than 20 , so these data are not reported. To calculate the potential for a bird species to serve as a vector for dwarf mistletoe, the habitat priority and frequency of occurrence factors were multiplied together. The higher the resulting vector potential the higher the species potential in epizoochory. Generally, I regard species with a vector potential value greater than 100 as likely to be important in the transport of dwarf 
TABLE I I

SPECIES COMMONLY FOUND IN INFECTED

AND INFECTIBLE TREES

Species $\begin{aligned} & \text { Regions }{ }^{1} \text { Habitat }{ }^{2} \\ & \text { Observed Preference Frequency }{ }^{3} \text { Potential } 4\end{aligned}$

Red-Breasted Nuthatch

$E, W$

100

500

Sitta canadensis

White-Breasted Nuthatch E,W

5

90

450

Sitta carolinensis

B lack-Capped Chickadee E,W

Parus atricapillus

Mountain Chickadee

E

5

90

450

Parus gambeli

Pine Siskin

$E, W$

5

70

350

Spinus pinus

Evening Grosbeak

Hesperiphona vespertina

Steller's Jay

$E, W$

5

60

300

Cyanocitta stelleri

$E, W$

5

50

250

Hairy Woodpecker

E

Dendrocopos villosus

Oregon Junco

$E, W$

3

50

450

Junco oreganus

Western Robin

$E, W$

3

50

40

$160^{5}$

Turdus migratorius

Gray Jay

E

Perisoreus canadensis

Red-Shafted Flicker

Colaptes cafer

$$
E, W
$$

4

5

20

100

Red Crossbill

E

5

20

100

Loxia curvirostra

Western Bluebird

E

3

30

90

Sialia mexicana

American Goldfinch

E

3

30

90 


\section{TABLE II (Continued)}

\section{SPECIES COMMONLY FOUND IN INFECTED} AND INFECTIBLE TREES

\begin{tabular}{|c|c|c|c|c|}
\hline Species & $\begin{array}{l}\text { Regions } \\
\text { Observed } \\
\end{array}$ & $\begin{array}{r}\text { Habitat } \\
\text { Preference } \\
\end{array}$ & Frequency ${ }^{3}$ & ${ }^{3}$ potential 4 \\
\hline $\begin{array}{l}\text { Audubon's Warbler } \\
\text { Dendroica auduboni }\end{array}$ & $\mathrm{E}$ & 4 & 20 & 80 \\
\hline $\begin{array}{l}\text { Downy Woodpecker } \\
\text { Dendrocopos pubescens }\end{array}$ & $E, W$ & 4 & 20 & 80 \\
\hline $\begin{array}{l}\text { Townsend's Solitaire } \\
\text { Myadestes townsendi }\end{array}$ & $\mathrm{E}$ & 4 & 20 & 80 \\
\hline $\begin{array}{l}\text { Chipping Sparrow } \\
\text { Spizella passerina }\end{array}$ & $E, W$ & 3 & 20 & 60 \\
\hline $\begin{array}{l}\text { Rufous-Sided Towhee } \\
\text { Pipilo erythrophthalmu }\end{array}$ & us $E$ & 3 & 20 & 60 \\
\hline $\begin{array}{l}\text { Lesser Goldfinch } \\
\text { Spinus psaltria }\end{array}$ & $\mathrm{E}$ & 3 & 20 & 60 \\
\hline $\begin{array}{l}\text { Common Bushtit } \\
\text { Psaltriparus minimus }\end{array}$ & W & 5 & -- & $\ldots--6$ \\
\hline $\begin{array}{l}\text { Pigmy Nuthatch } \\
\text { Sitta pygmaea }\end{array}$ & E & 5 & $\cdots$ & $\ldots 6$ \\
\hline $\begin{array}{l}\text { Clark's Nutcracker } \\
\text { Nucifraga columbiana }\end{array}$ & $\mathrm{E}$ & 5 & $\ldots$ & $\ldots 6$ \\
\hline $\begin{array}{l}\text { Brown Creeper } \\
\text { Certhia familiaris }\end{array}$ & $\mathrm{E}$ & 5 & $\cdots$ & $\ldots 6$ \\
\hline
\end{tabular}

1 "E" means east slope regions $(1,2,3, \& 4)$; "W" means west slope region 5 .

2 Habitat values reflect the of time these species spent in infected and infectible trees. A value of 5 means that of the total time I observed the species 81 to $100 \%$ of that time the birds were in host trees. A value of 4 means 61 to $80 \%, 3$ means 41 to $60 \%, 2$ means 21 to $40 \%$ and 1 means 1 to $20 \%$.

3 Frequency values are based upon the number of observations of the species in question relative to the total number 
TABLE II (Continued)

\section{SPECIES COMMONLY FOUND IN INFECTED AND INFECTIBLE TREES}

of Red-Breasted Nuthatch observations. During the period of Ausut through 0ctober 1972 , I recorded seeing 280 Red-Breasted Nuthatches. These sightings ranged in duration from a matter of seconds to an hour or so.

4 Vector Potential = Habitat Preference $x$ Frequency and is the potential for species to move seeds of dwarf mistletoe.

Although the species has a high Vector Potential, I do not consider this species to be a potential spreader of Arceuthobium seeds due to its over-all behavior.

6

I have not calculated vector Potentials for birds with

a Frequency less than 20 due to the inaccuracy of those data. 
TABLE I I I

ADDITIONAL SPECIES OBSERVED IN INFECTED TREES

\begin{tabular}{|c|c|c|c|}
\hline Species & $\begin{array}{l}\text { itat } \\
\text { rence }\end{array}$ & Species & $\begin{array}{l}\text { itat } \\
\text { rence }\end{array}$ \\
\hline $\begin{array}{l}\text { Turkey Vulture } \\
\text { Cathartes aura }\end{array}$ & 1 & $\begin{array}{l}\text { Western Wood Pewee } \\
\text { Contopus sordidulus }\end{array}$ & 3 \\
\hline $\begin{array}{l}\text { Marsh Hawk } \\
\text { Circus cyaneus }\end{array}$ & 1 & $\begin{array}{l}\text { Scrub Jay } \\
\text { Aphelocoma coerulescens }\end{array}$ & 2 \\
\hline $\begin{array}{l}\text { Goshawk } \\
\text { Accipiter gentilis }\end{array}$ & 1 & $\begin{array}{l}\text { Magpie } \\
\text { Pica pica }\end{array}$ & 2 \\
\hline $\begin{array}{l}\text { Red-Tailed Hawk } \\
\text { Buteo jamaicensis }\end{array}$ & 1 & $\begin{array}{l}\text { Raven } \\
\text { Corvus corax }\end{array}$ & 2 \\
\hline $\begin{array}{l}\text { Golden Eagle } \\
\text { Aquila chrysaetos }\end{array}$ & 1 & $\begin{array}{l}\text { Common Crow } \\
\text { Corvus brachyrhynchos }\end{array}$ & 3 \\
\hline $\begin{array}{l}\text { Osprey } \\
\text { Pandion haliaetus }\end{array}$ & 1 & $\begin{array}{l}\text { Dipper } \\
\text { Cinclus mexicanus }\end{array}$ & 1 \\
\hline $\begin{array}{l}\text { Ruffed Grouse } \\
\text { Bonasa umbellus } \\
\end{array}$ & 2 & $\begin{array}{l}\text { Varied Thrush } \\
\text { Ixoreus naevius }\end{array}$ & 3 \\
\hline $\begin{array}{l}\text { California Quail } \\
\text { Lophortyx californicus }\end{array}$ & 1 & $\begin{array}{l}\text { Swainson's Thrush } \\
\text { Hylocichla ustulata }\end{array}$ & 2 \\
\hline $\begin{array}{l}\text { Mountain Quail } \\
\text { Oreortyx pictus } \\
\end{array}$ & 1 & $\begin{array}{l}\text { Mountain Bluebird } \\
\text { Sialia currucoides }\end{array}$ & 2 \\
\hline $\begin{array}{l}\text { Band-Tailed Pigeon } \\
\text { Columba fasciata }\end{array}$ & 3 & $\begin{array}{l}\text { Golden-Crowned Kinglet } \\
\text { Regulus satrapa }\end{array}$ & $+^{2}$ \\
\hline $\begin{array}{l}\text { Mourning Dove } \\
\text { Zenaidura macroura }\end{array}$ & 2 & $\begin{array}{l}\text { Ruby-Crowned Kinglet } \\
\text { Regulus calendula }\end{array}$ & + \\
\hline $\begin{array}{l}\text { Great Horned Ow } \\
\text { Bubo virginianus } \\
\end{array}$ & 2 & $\begin{array}{l}\text { Cedar Waxwing } \\
\text { Bombycilla cedrorum }\end{array}$ & 4 \\
\hline $\begin{array}{l}\text { Pigmy Owl } \\
\text { Giaucidium gnoma }\end{array}$ & 2 & $\begin{array}{l}\text { Solitary Vireo } \\
\text { Vireo solitarius }\end{array}$ & + \\
\hline $\begin{array}{l}\text { Belted Kingfisher } \\
\text { Megaceryle alcyon }\end{array}$ & 2 & $\begin{array}{l}\text { Hutton's Vireo } \\
\text { Vireo huttoni }\end{array}$ & + \\
\hline $\begin{array}{l}\text { Lewis Woodpecker } \\
\text { Asyndesmus lewis }\end{array}$ & 4 & $\begin{array}{l}\text { Warbling Vireo } \\
\text { Vireo gilvus }\end{array}$ & + \\
\hline
\end{tabular}


TABLE III (Continued)

ADDITIONAL SPECIES OBSERVED IN INFECTED TREES ${ }^{1}$

$\begin{array}{lrl}\text { Species } & \text { Habitat } & \text { Habitat } \\ \text { Preference species } & \text { Preference }\end{array}$

Yellow-Bellied Sapsucker 3

Sphyrapicus varius

Williamson's Sapsucker

Sphyrapicus thryoideus

Three-Toed Woodpecker 4

Picoides tridactylus

Traill's Flycatcher

Empidonax traillii

Hammond's Flycatcher

Empidonax hammondii

Western Flycatcher

Empidonax difficilis

Olive-Sided Flycatcher

Nuttallornis borealis

Brewer's Blackbird

Euphagus cyanocephalus

Western Tanager

Piranga ludoviciana

B lack-Headed Grosbeak 2

Pheucticus melanocephalus

Cassin's Finch

Carpodacus cassinii

Pine Grosbeak.

Pinicola enucleator

Gray-Crowned Rosy Finch + Leucosticte tephrocotis

3

3

2
Orange-Crowned Warbler +

Vermivora celata

4 Yellow Warbler

Dendroica petechia

Myrtle Warbler

Dendroica coronata

Townsend's Warbler

Dendroica townsendi

3 B lack-Throated Gray

Warbler

Dendroica nigrescens

Red-Winged Blackbird Agelaius phoeniceus

$+\quad$ Slate-Colored Junco

Junco hyemalis

Golden-Crowned Sparrow 3

Zonotrichia atricapilla

Fox Sparrow

Passerella iliaca

Lincoln's Sparrow

Melospiza lincolnii

Song Sparrow
1

3

3

1

2

1

3

Melospiza melodia

1

This table, in conjunction with Table II, comprises a list of all the bird species I observed and identified in infected and infectible trees in my study areas during the fall of 1972. Frequency values for the species listed are 
TABLE III (Continued)

ADDITIONAL SPECIES OBSERVED IN INFECTED TREES 1

less than 20 and consequently are not reported.

$2+\quad$ Indicates species for which I was unable to make sufficient observations to assign habitat values. 
mist letoe.

The most common birds capable of distributing Arceuthobium seeds are listed in Table 2 with values of 100 or more. The four members of the closely related families Paridae and Sittidae are the most important of these. These four species often form flocks of about ten individuals when feeding. It was most common though to find the RedBreasted Nuthatch and the Mountain Chickadee together and the White-Breasted Nuthatch and the Black-Capped Chickadee together. Often kinglets, creepers and bushtits also accompany these flocks. These groups fly from tree to tree hunting insects. They search through whole trees but spend a significant amount of time in the youngest and thus most infectible portions of trees. I often observed flocks of these birds in mixed infected stands of Western Larch (Larix occidentalis), Ponderosa Pine (Pinus ponderosa), Grand Fir (Abies grandis), Douglas Fir (Pseudotsuga menziesii) and Western Juniper (Juniperus brevifolia). The whole flock would begin hunting in three or four trees and then slowly break up into groups of one, two or three individuals as it moved through the forest. The net movement resulted in the flock feeding in many but not all of the trees encountered in the area. After twenty or thirty minutes the whole flock, in surprising unison, would take off and fly for a distance of approximately 100 meters and begin feeding in a new group of trees. The new feeding area looked, to me, 
no different than that they had just left, or area they passed by. I was unable to detect any preference by these flocks for a particular tree species, or a preference for trees infected by or free of dwarf mistletoe. The only exception was that they stayed out of stands of pure juniper.

Members of the family Corvidae are also significant as potential spreaders of the disease (Table II). The Steller's Jay, Gray Jay and Clark's Nutcracker are all permanent residents of coniferous forests. All three spend a majority of the time in coniferous trees. Of these three, the habits of the Steller's Jay make it particularly important as a potential vector for mistletoe transport. This species is gregarious and spends most of its time in flocks in the forest hunting food from trees. Generally, when the birds are in the lower portions of the tree they prefer perches, often dead limbs, near the main stem of the tree. As they move up the tree to the top, they land in younger, more infectible portions of the tree. The flock's pattern of movement through a forest is similar to that illustrated in Figure 3 .

The sequence of perches affords the jays maximum cover while at the same time affording them excellent vantage points. Often the flock will move slowly through a group of trees calling, swooping to the ground to feed, preening, etc. When they are not actively hunting, they often spend 
time in the highest perches watching and preening. I have seen a number of jays preening their feathers in the very highest portions of large forest trees among dense foliage. These regions of the conifers are highly infectible due to their age and they also have a greater potential for establishing new infections in the surrounding trees (Smith, $1973)$

Clark's Nutcracker is similar to the jays in that it has gregarious habits, but I observed it feeding almost entirely on conifer seeds and insects. They spend most of their time feeding on cones in the perimeter of trees, the most infectible area of those trees (Figure 4).

The three fringillid species listed with high vector potential values are the Pine Siskin, Evening Grosbeak and the Red Crossbill. Of these, only the Pine Siskin was easily observed. This is a gregarious species. Flocks of them could be seen feeding on almost any seed source; among the most common were conifers. The Pine Siskin and Clark's Nutcracker were the most common birds I saw near the timberline areas. I often saw them in infected trees feeding on cones. I also observed these birds preening and wiping their bills in infectible areas of these trees. These birds are permanent residents of the state where, during the summer, they are alpine and sub-alpine inhabitants. The Pine Siskins then move down slope, both east and west of the Cascade Crest, during the colder weather of fall and winter. 


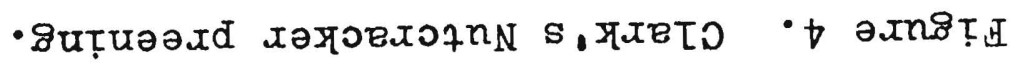

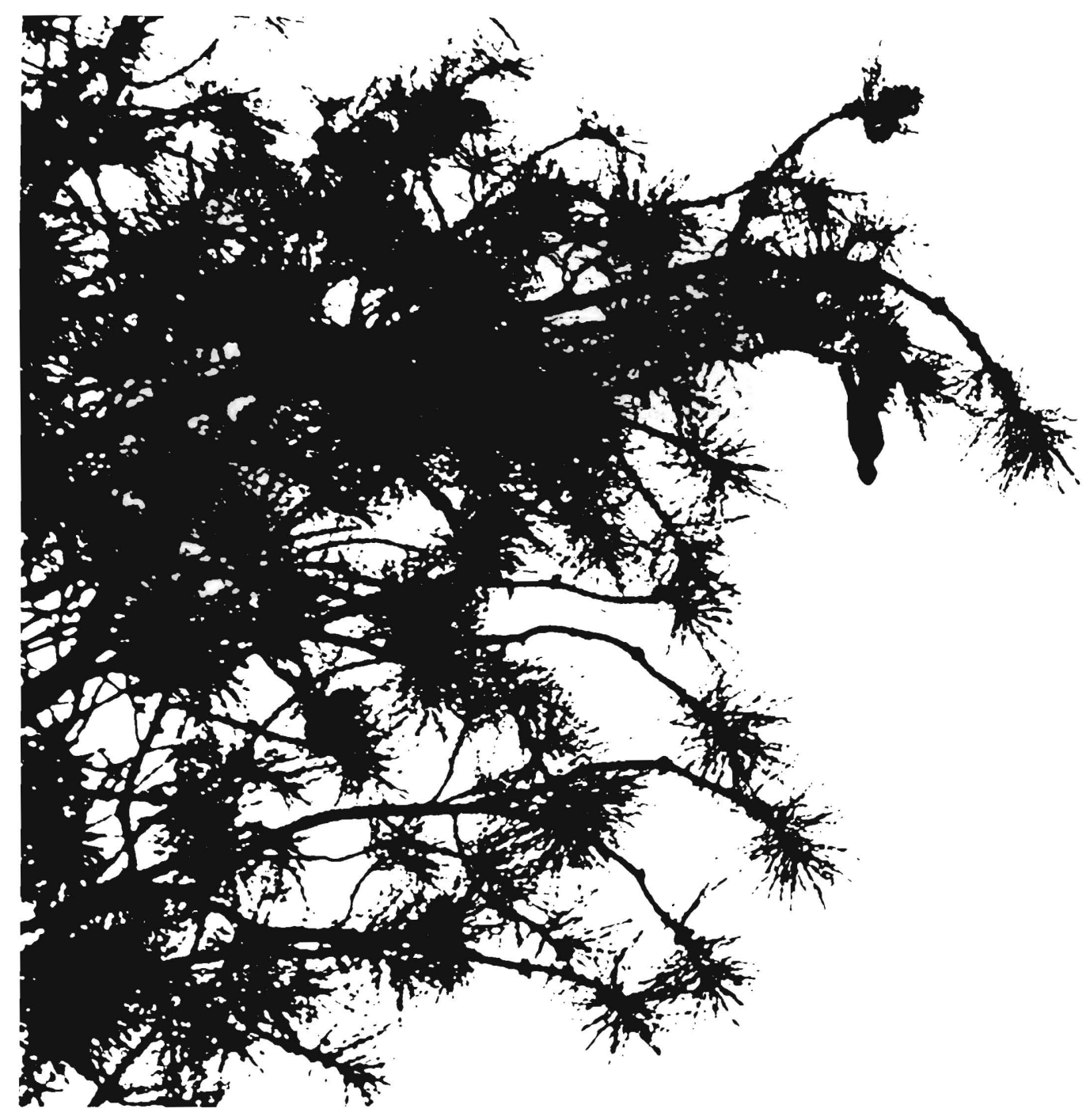


I consider the Pine Siskin the most likely avian vector for the movement of A. douglasii from the east slope of the Cascades to the west slope.

The other two fringillid species are both extremely hard to observe and I have only limited data concerning them. The Evening Grosbeak spent some time in the lower sections of the trees and on the ground feeding, but the Red crossbill, during my observation periods, fed almost exclusively on cones in the canopy of the tallest conifers. These species spent a large portion of their time in infectible portions of the trees. The Evening Grosbeak has been reported feeding on the aerial portions of mistletoe plants (Marshall, 1957; Hawksworth, 1961), although I observed no such activity. I have seen crossbills high in the tops of infected trees apparently reacting to being hit by fired seeds. On one occasion I was watching (using a spotting scope) a small group of crossbills feeding on cones about 100 yards away in the top of a very large pine. Three more crossbills landed near these birds which were near a large infection. (Von Schrenk (1900) notes that even the slight movement of a host branch, such $a \dot{s}$ caused by the lighting of a bird may result in a fusillade of Arceuthobium seeds.) Immediately, all the birds flew. I had been watching this group of birds for about fifteen minutes and in my opinion their behavior was a reaction to being hit by fired seeds rather than a response to any other stimulus. I saw one of them land and begin 
preening its feathers and wiping its bill on a young limb. My observation of birds in hemlock forests west of the Cascade Crest was limited in comparison to work in the east slope forests. A. tsugense seeds mature later than any other mistletoe in oregon, but there is a time overlap with east slope species and I spent most of that overlap time on the east slope. Due to the limited observation time and the difficulty in making observations in the dense west slope forests, I was able to complete only a partial species list. Over-all, I saw fewer birds in the hemlock forests; however, I did observe potential spreaders of the parasite. The most likely of these are the Common Bushtit, the BlackCapped Chickadee and the White-Breasted Nuthatch. Although, the Common Bushtit is very similar to the other parids already discussed, there are several distinctive aspects of their behavior that should be noted. They are considerably smaller than the chickadees and nuthatches they commonly flock with. Consequently, they spent much time in the youngest portions of the tree (increasing their potential as vectors.) They are common in stands of young trees and $I$ often observed them in newly regenerated areas. Their flocks are much tighter and larger than those of the other members of the Paridae I observed. It was common to see and hear groups of fifteen or twenty individuals in a single young tree.

The Band-Tailed Pigeon is another species that is less 
common east of the crest of the Cascades and a species that in my observations was primarily a ground feeder. However, I observed a particular trait that could be important in the distribution of A. tsugense. It fed on the ground where it quickly filled its crop with seeds. When the crop was full the bird flew to a high perch. The band-tail is a large bird, yet it often picked the leader of a hemlock tree for its perch. I have watched them preening in this position and cleaning their beaks on their perch as they digest their meal. This habit of picking the leader for a perch is a common attribute of large seed-eating birds. I often observed Ruffed Grouse in the same portions of trees after feeding. Both use younger portions of the tree for night perches. For this reason members of the families Tetraonidae and Columbidae could be much more important in the distribution of dwarf mistletoe than one would expect of large ground feeding birds. This is particularly important since the tetraonids are reported to feed on aerial portions of dwarf mistletoe during the fall (Wagner, 1968; Weir, 1916a, 1916b). of the fifteen bird species listed as likely distributors of dwarf. mistletoe in oregon, eleven are permanent residents of the coniferous forests. The Paridae are known to migrate south occasionally, particularly during extremely harsh winters, but generally they remain in the forest throughout the winter and migrate down slope (in any compas direction) with colder weather. A common argument against 
the epizoochory of dwarf mistletoe by birds is that bird migration patterns are such that they would constitute an influence only on the southward movement of the parasite. Obviously, this does not apply to permanent residents of the state, since they will move locally throughout the forest in the fall. They have only to move the seeds $15 \mathrm{ft} . / \mathrm{yr}$. to increase the rate of spread of dwarf mistletoe by one order of magnitude. In fact, birds could be routinely carrying and depositing the seeds at much greater distances than that from their source.

On the other hand, migratory forest passerines might be a factor in the distribution of A. douglasii in southwest Oregon. Douglas fir is infected with A. douglasii primarily on the east side of the Cascade Divide into southwest oregon and northern California. This is the same route that a number of migratory bird species follow (Dorst, 1962). Many of these migratory birds are summer residents of the area between the Rockies and Cascades in Oregon, Washington and Canada. These birds, in migrating south for the winter, cross the Cascade Divide at the Umpqua River headwaters or near Mt. Shasta in California and then follow the valleys between the coast and Cascade ranges in oregon and the Sierras and the coast in California. It should be noted though that recent studies have shown A. douglasii does occur west of the Cascade Crest in Oregon in both the willamette and Mt. Hood National Forests (Hawksworth and Wiens, 1972; 
personal communication 2 July 1972 from Robert 0 . Tinnin, Biology Department, Portland State University, Portland, Oregon) and in Washington in White Pass (Wicker, 1969).

Avian hygenic habits may be the single most important factor in short range epizoochory of dwarf mistletoe. I observed that individuals of most species of birds often choose dense foliage for night perches. I have observed many species of birds giving their first morning songs from brooms in infected trees. Smith (1973) has shown that the seeds of A. tsugense are fired around the clock (although 2-5 times as many seeds are fired during the daylight hours as at night). It seems likely that a bird perched in a broom through nine hours of darkness would be hit by seeds or pick them up on its feet. Further, I observed that most passerines bathed in a dew source in the early morning. After wetting themselves, they flew to high perches, and sat in the sun to preen and dry their feathers. Since most of the bathing occurred early in the morning, the sun's rays were still high in the canopy. Thus, the birds usually perched on young branches near the top of a tree. The whole process is often completed within several hundred yards of the previous night's perch and applies to most forest birds. My observations show that birds do pick up seeds of dwarf mistletoe both by being hit by fired seeds (I observed 28 obvious instances of this) or possibly by contact with fired seeds either on the ground or from foliage. In the 
process of bathing and preening, birds may transport seeds to a new host thus potentially initiating a new infection. By this procedure, almost any bird in the forest is capable of dwarf mistletoe epizoochory.

I attempted to trap birds during the time of active seed dispersal to see if they were carrying seeds but was unsuccessful. Using a mist net, I caught a Chipping Sparrow. I examined it for seeds on its feathers and found what I believe to have been a dwarf mistletoe seed. I placed the bird in a portable cage, but it soon escaped. Several days later I received communication that George Huddler in Minnesota was working on the same problem by shooting birds and examining their feathers. I, therefore, concentrated on observations.

The observations of Hawksworth (1961) illustrate feed: ing as a possible means of dispersal. He mentions he had once seen Evening Grosbeaks feeding on aerial portions of A. campylopodium and finding voided seeds in theirs and other droppings. He stated that therefore feeding on dwarf mistletoe is not rare, but viability of voided seeds is likely to be verry low.

During the four month period of field study, I did not observe any birds feeding on dwarf mistletoe seeds or fruits or aerial shoots. In addition, I was unable to distinguish any seeds of dwarf mistletoe in the hundreds of bird droppings I checked in the field. This agrees with the 
observations of Dr. Paul Baldwin who, after examining the stomach contents of approximately 150 forest passerines collected from the forests around Ft. Collins, Colorado said:

I have looked at most of this material, in addition to large numbers of stomach samples of woodpeckers and numerous forest passerines. Although alerted to the mistletoe (Arceuthobium) dispersal problem, I have yet to recognize a mistletoe seed in any bird stomach sample. (Personal communication 15 April 1973 from Paul Baldwin, Zoology Department, Colorado State University, Ft. Collins, Colorado).

\section{Capture and Feeding Experiments}

Feeding captive birds was attempted during the winter of 1972 at my home in Portland, Oregon. By using mist nets and Sherman Museum Traps, I captured several birds.

The feeding of captured birds was intended to test two hypotheses. The first was that common forest passerines do not regularly feed on dwarf mistletoe seeds and even when they do, few seeds remain viable. Secondly, the important potential vectors of dwarf mistletoes are content to leave the seeds on their feathers until they bathe. I also wanted to find out how easily the seeds stuck to their feathers and whether the seeds could be removed easily by the bird after the viscin dried. Although I caught twelve species of birds over the winter, I concentrated on the three species that seemed likely spreaders of the parasite - the Steller's Jay, the Black-Capped Chickadee and the Oregon Junco.

After capture the birds were placed in a cage that was covered with a white sheet to keep the birds calm. These 
birds were presented with several food and watched for their reaction to dwarf mistletoe seeds. Although the birds did feed on other sources, as far as I can tell, Arceuthobium seeds were not eaten even when they were the only food source available. Ten out of 100 seeds were unaccounted for. I was unable to find dwarf mistletoe seed remnants in the droppings of the three captured species.

I placed seeds on the feathers of all captured individuals. Four moist seeds were placed on each bird and the individuals were then checked twice daily for the presence of the seeds. All birds were supplied with bath water, yet only one of the six steller's Jays bathed. On the second day this bird removed three of the four seeds after bathing. All birds were released after three days if they were still alive. All 17 other individuals had all four seeds on their feathers at the time of release or death. These captive birds were very skittish and none of them became calm during the three day capture period.

The results of these studies were inconclusive, except that I found that dwarf mistletoe seeds stick readily to the feathers of birds. However, these data, along with my field and feeder observations and Baldwin's statement, do supply evidence against regular avian feeding on dwarf mistletoe seeds in this area. Additionally, I believe that if feeding does occur it would constitute more of an influence as a control of dwarf mistletoe rather than a dispersal mechanism. 


\section{Feeder Observations}

Although dwarf mistletoe seeds were available at my bird feeder for almost two months during the winter and I had nearly two dozen species of birds visit the feeder during that period, I never saw birds feed on the seeds. Slowly, over that period, though, seeds did disappear. I placed a total of 320 seeds at the feeder over the two month period and they all disappeared from the feeder. Probably most of them were kicked to the ground by birds and squirrels or washed away by rain. By spring a number of seeds were still on the ground around the feeder. I did find one seed on a young hemlock tree about twenty feet from the feeder (see Figure 5). It may have been carried from the feeder on the feet of one of the feeding birds. There are no infected trees within several miles of the feeder.

Seeds on Nesting Materials

Ridley (1930) notes that birds, in collecting materials for the construction of their nests, frequently carry branches of herbs or shrubs, panicles of grass with attached seeds, plumed seeds to line the nests, or portions of living plants (which may continue to grow) back to the nest site. Although there are no references in the literature concerning dwarf mistletoe movement as a result of nest building, my studies show that forest passerines do bring viable seeds to their nesting sites. 


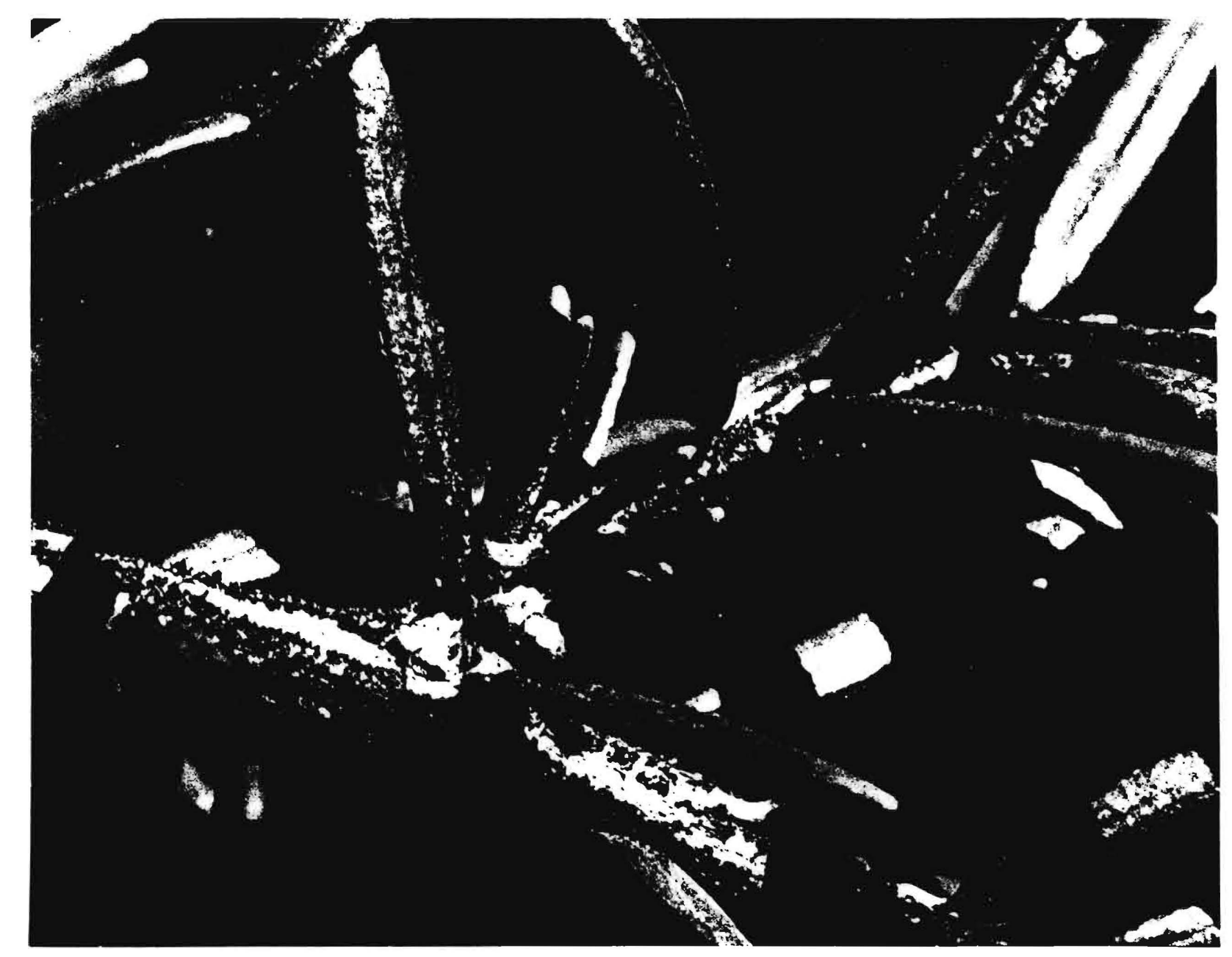

Figure 5. Dwarf mistletoe seed on a hemlock tree near my feeder. 
Although there are a large number of seeds available on the ground in the fall, my observations show most of these seeds are gone or are inviable by spring. The result is that even though birds use materials collected from the forest floor for nesting, most of these are free of dwarf mistletoe seeds. On the other hand, mosses and lichens are an excellent reservoir for Arceuthobium seeds. The seeds seem to overwinter on these plants and the seeds are viable when the nesting season begins during the spring. Table IV is a list of birds known to nest in oregon. I have included in the list only those birds that frequent forested areas, that nest in the infectible portions of host trees and that use materials for nesting that are likely to contain dwarf mistletoe seeds.

I collected seven nests during the spring and summer of 1973 and five had dwarf mistletoe seeds on them. Most commonly, these seeds appeared to have been taken to the nest on lichen material used in construction. The five nests that contained seeds all had lichens, mosses or both in them. The other two nests were void of 1 ichens and mosses; they were made of diry grasses in one case and sticks and twigs in the other.

On the nest of a western Flycatcher I found three viable seeds that had formed holdfasts on nesting materials. On the active nest of a Hammond's Flycatcher I found four seeds. I removed them and left the nest. None of these 
TABLE IV

BIRDS OF OREGON THAT BUILD NESTS IN INFECTIBLE PORTIONS OF HOST TREES

Species

Band-Tailed Pigeon

Columba fasciata

Mourning Dove

Zenaidura macroura

Broad-Tailed Hummingbird

Selasphorus platycercus

Calliope Humingbird Stellula calliope

Rufous Hummingbird

Selasphorus rufus

Allen's Hummingird Selasphorus sasin

Traill's Flycatcher Empidonax trail1ii

Hammond's Flycatcher

Empidonax hammondi i

Gray Flycatcher

Empidonax wrightii

Western Flycatcher

Empidonax difficilis

Western Wood Pewee

Contopus sordidulus

01 ive-Sided Fiycatcher

Nuttallornis borealis

Steller's Jay

Cyanocitta stelleri

Gray Jay

Perisoreus canadensis

Clark's Nutcracker

Nucifraga columbiana
Region Habitat ${ }^{2}$ Material

A11 1 Trees Twigs

A11 Trees Twigs

$C, D, E$ Trees Plant fibers, Lichens

$C, D, E$ Conifers Plant down, Bark

A11 Trees Plant fibers, Lichens

B, C,E Trees Plant Down, Moss

A11 Small Plant fibers, Trees Pine needles

$C, D, E$ Small Plant fibers, Trees Moss

A, B Smal1 Bark, Moss,

A, B Small Plant fibers, Trees Roots, Moss

A11 Trees Plant fibers

Moss, Lichens

A11 Conifers Lichens,

Fibers

A11 Trees Twigs, Grass, Mud, sticks

B, C, D Conifers Lichens, Moss, Twigs, Grass

C, D,E Conifers Lichens, Twigs, Bark 
TABLE IV (Continued)

\section{BIRDS OF OREGON THAT BUILD NESTS IN INFECTIBLE PORTIONS OF HOST TREES}

\begin{tabular}{|c|c|c|c|}
\hline & & 2 & \\
\hline Species & Region & Habitat & Material \\
\hline $\begin{array}{l}\text { Common Bushtit } \\
\text { Psaltriparus minimus }\end{array}$ & $A, B, C$ & Trees & Lichens, Moss \\
\hline $\begin{array}{l}\text { Catbird } \\
\text { Dumetella carolinensis }\end{array}$ & D & $\begin{array}{l}\text { Small } \\
\text { Trees }\end{array}$ & Rootlets \\
\hline $\begin{array}{l}\text { Robin } \\
\text { Turdus migratorius }\end{array}$ & A 11 & Trees & $\begin{array}{l}\text { Mud, Grass, } \\
\text { Rootlets }\end{array}$ \\
\hline $\begin{array}{l}\text { Varied Thrush } \\
\text { Ixoreus naevius }\end{array}$ & Similar to & those of & f the Robin \\
\hline $\begin{array}{l}\text { Swainson's Thrush } \\
\text { Hylocichla ustulata }\end{array}$ & $A, B, C$ & $\begin{array}{l}\text { Sma } 11 \\
\text { Trees }\end{array}$ & Moss, Bark \\
\hline $\begin{array}{l}\text { Ruby-Crowned Kinglet } \\
\text { Regulus calendula }\end{array}$ & A 11 & $\begin{array}{l}\text { Limb of } \\
\text { Conifer }\end{array}$ & $\begin{array}{l}\text { Moss, Lichens, } \\
\text { Bark(Pendant) }\end{array}$ \\
\hline $\begin{array}{l}\text { Cedar Waxwing } \\
\text { Bombycilla cedrorum }\end{array}$ & A 11 & $\begin{array}{l}\text { Sma } 11 \\
\text { Trees }\end{array}$ & $\begin{array}{l}\text { Sticks, Weeds, } \\
\text { Fibers }\end{array}$ \\
\hline $\begin{array}{l}\text { Solitary Vireo } \\
\text { Vireo solitarius }\end{array}$ & A 11 & $\begin{array}{l}\text { Small } 1 \\
\text { Trees }\end{array}$ & $\begin{array}{l}\text { Moss, Grass, } \\
\text { Hanging nest }\end{array}$ \\
\hline $\begin{array}{l}\text { Hutton's Vireo } \\
\text { Vireo huttoni }\end{array}$ & $A, B$ & Trees & $\begin{array}{l}\text { Moss, Grass, } \\
\text { (Hanging) }\end{array}$ \\
\hline $\begin{array}{l}\text { Red-Eyed Vireo } \\
\text { Vireo olivaceus }\end{array}$ & A 11 & $\begin{array}{l}\text { Low in } \\
\text { Trees }\end{array}$ & $\begin{array}{l}\text { Bark, Fibers, } \\
\text { Wool, Cup Type }\end{array}$ \\
\hline $\begin{array}{l}\text { Warbling Vireo } \\
\text { Vireo gilvus }\end{array}$ & A 11 & $\begin{array}{l}\text { Similar tc } \\
\text { Vireo }\end{array}$ & to Red-Eyed \\
\hline $\begin{array}{l}\text { Yellow Warbler } \\
\text { Dendroica petechia }\end{array}$ & A 11 & $\begin{array}{l}\text { Low in } \\
\text { Trees }\end{array}$ & $\begin{array}{l}\text { Cup of plant, } \\
\text { Fibers }\end{array}$ \\
\hline $\begin{array}{l}\text { Myrtle Warbler } \\
\text { Dendroica coronata }\end{array}$ & (Uncommon) & Conifers & $\begin{array}{l}\text { Grass, Twigs, } \\
\text { Lichens }\end{array}$ \\
\hline $\begin{array}{l}\text { Audubon's warbler } \\
\text { Dendroica auduboni } \\
\end{array}$ & A 11 & $\begin{array}{l}\text { Sma } 11 \\
\text { Trees }\end{array}$ & $\begin{array}{l}\text { Bark, Pine } \\
\text { Needles }\end{array}$ \\
\hline $\begin{array}{l}\text { Townsend's Warbler } \\
\text { Dendroica townsendi }\end{array}$ & $C, D$ & $\begin{array}{l}\text { Small } \\
\text { Conifers }\end{array}$ & $\begin{array}{l}\text { Moss, Grass, } \\
\text { Lichens }\end{array}$ \\
\hline
\end{tabular}


TABLE IV (Continued)

BIRDS OF OREGON THAT BUILD NESTS IN INFECTIBLE PORTIONS OF HOST TREES

\begin{tabular}{|c|c|c|c|}
\hline Species & Region & $\mathrm{Habitat}^{2}$ & Material \\
\hline $\begin{array}{l}\text { Hermit Warbler } \\
\text { Dendroica occidentalis }\end{array}$ & $A, B$ & $\begin{array}{l}\text { Sma } 11 \\
\text { Conifers }\end{array}$ & $\begin{array}{l}\text { Stems, Lichens, } \\
\text { Needles }\end{array}$ \\
\hline $\begin{array}{l}\text { B lack-Throated Gray Warbler } \\
\text { Dendroica nigrescens }\end{array}$ & $A, B, C$ & $\begin{array}{l}\text { Small } 1 \\
\text { Trees }\end{array}$ & Plant fibers \\
\hline $\begin{array}{l}\text { American Redstart } \\
\text { Setophaga ruticilla }\end{array}$ & $\mathrm{D}$ & Trees & $\begin{array}{l}\text { Plant fibers, } \\
\text { Bark, Down }\end{array}$ \\
\hline $\begin{array}{l}\text { Bullock's oriole } \\
\text { Icterus bullockii }\end{array}$ & A 11 & Trees & $\begin{array}{l}\text { Grasses, Bark, } \\
\text { (Pendant) }\end{array}$ \\
\hline $\begin{array}{l}\text { Western Tanager } \\
\text { Piranga ludoviciana }\end{array}$ & A 11 & $\begin{array}{l}\text { Low in } \\
\text { Trees }\end{array}$ & Twigs, Grass \\
\hline $\begin{array}{l}\text { Black-Headed Grosbeak } \\
\text { Pheucticus melanocephalus }\end{array}$ & A 11 & $\begin{array}{l}\text { Smal1 } \\
\text { Trees }\end{array}$ & Twigs, Weeds \\
\hline $\begin{array}{l}\text { Evening Grosbeak } \\
\text { Hesperiphona vespertina }\end{array}$ & A 11 & Conifers & Sticks, Roots \\
\hline $\begin{array}{l}\text { Cassin's Finch } \\
\text { Carpodacus cassinii }\end{array}$ & A 11 & $\begin{array}{l}\text { Small } \\
\text { Conifers }\end{array}$ & $\begin{array}{l}\text { Rootlets } \\
\text { Grass }\end{array}$ \\
\hline $\begin{array}{l}\text { Pine Grosbeak } \\
\text { Pinicola enucleator }\end{array}$ & D & Conifers & $\begin{array}{l}\text { Rootlets, } \\
\text { Twigs }\end{array}$ \\
\hline $\begin{array}{l}\text { Pine Siskin } \\
\text { Spinus pinus }\end{array}$ & A 11 & Conifers & $\begin{array}{l}\text { Moss, Lichens, } \\
\text { Twigs, Hair }\end{array}$ \\
\hline $\begin{array}{l}\text { Red Crossbill } \\
\text { Loxia curvirostra }\end{array}$ & $A, B$ & Trees & $\begin{array}{l}\text { Twigs, Bark, } \\
\text { Roots }\end{array}$ \\
\hline $\begin{array}{l}\text { Harris Sparrow } \\
\text { Zonotrichia querula }\end{array}$ & (rare) & Conifers & $\begin{array}{l}\text { Grass, Weeds, } \\
\text { Leaves }\end{array}$ \\
\hline $\begin{array}{l}\text { Fox Sparrow } \\
\text { Passerella iliaca }\end{array}$ & A11 & $\begin{array}{l}\text { Smal1 } \\
\text { Trees }\end{array}$ & $\begin{array}{l}\text { Plant fiber, } \\
\text { Grass }\end{array}$ \\
\hline $\begin{array}{l}\text { Lincoln's Sparrow } \\
\text { Melospiza lincolnii }\end{array}$ & A 11 & $\begin{array}{l}\text { Sma } 11 \\
\text { Trees }\end{array}$ & Grasses \\
\hline
\end{tabular}


TABLE IV (Continued)

BIRDS OF OREGON THAT BUILD NESTS IN INFECTIBLE PORTIONS OF HOST TREES

1 See Figure 6 for an explanation of the breeding regions of the state of oregon.

2 "Trees" implies both coniferous and deciduous species. This information was compiled from Gabrielson and Jewett

(1940) and Wetmore (1964). 


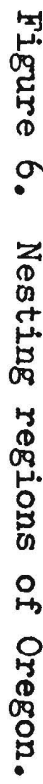

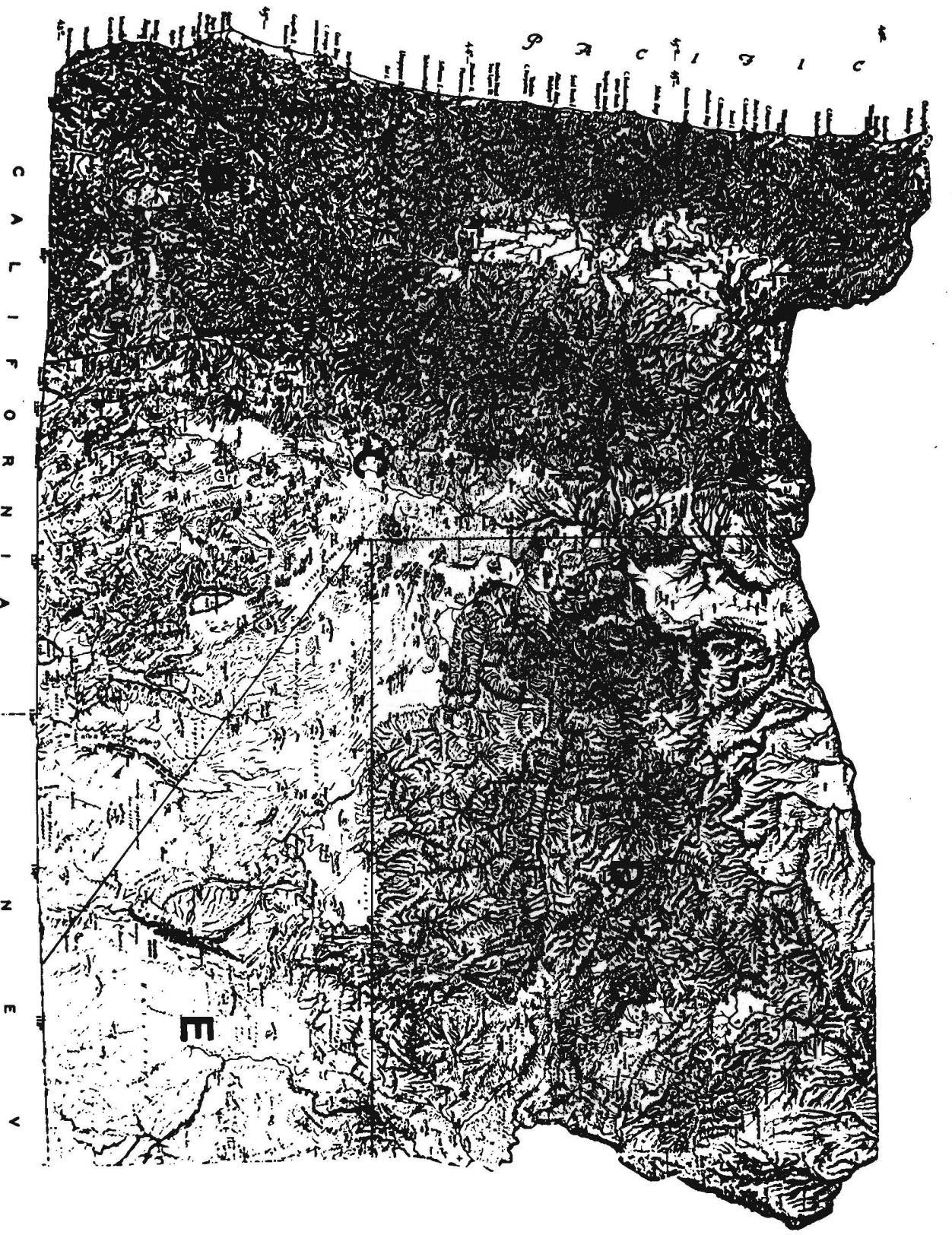


seeds had germinated and I returned them to the laboratory where they were placed in $2 \% \mathrm{H}_{2} \mathrm{O}_{2}$ in the dark at $15^{\circ} \mathrm{C}$. After two weeks three of the seeds had succumbed to fungal growth while one had germinated and formed a radicle. On the same day, I collected three seeds from lichens of trees in the same area and treated them to the same conditions as the seeds from the nest and all germinated.

Another factor in nesting is that many birds are sloppy in building their nests. In one active Robin's nest I found, on the limb below the nest, a quantity of nesting material. This nest was located about eighty feet into a clear cut on a fifteen year old Douglas fir tree. The collected material contained three germinating A. tsugense seeds which had formed holdfasts on twigs of the nest material.

Even though a rather unique set of circumstances must be met before a dwarf mistletoe seed on a nest cauld infect a tree, there are two aspects of nesting habits that could be especially important in increasing the probability of success. First, in coniferous forests of the Northwest, the species listed in Table IV tend to nest in two major types of habitat: the birds prefer young bushy trees where they usually build their nests less than eight feet from the ground in the bushiest part of the tree or they prefer the canopy of the forest, often nesting in a broom. Those birds nesting in brooms are, of course, no threat for dispersal. Nests in young trees, however, especially in the regrowth 
of clear cut areas, could constitute an important source of infection. It only takes one female seed placed centrally on young regrowth of a clear cut to reduce greatly the future yield of that whole area. Secondly, not all birds are exclusively spring nesters. Even one species that nests year around in the Northwest could be very important in the movement of dwarf mistletoe seeds. The pine Siskin is known to nest any time of year, and they have been noted to nest in brooms in trees. Generally thaugh, they prefer the ends of the limbs of young fir trees for their nests eight to twentyfive feet from the ground (Wetmore, 1964). Thus, the Pine Siskin's nesting during times of active seed dispersal could be extremely significant in the infection of regenerating stands. 


\section{CONCLUSIONS}

My observations confirm the statements of several authors that birds have an important potential role in the distribution of dwarf mistletoe.

Through persistent observation of forest birds I was able to accomplish an evaluation of this role. My observations point to three likely means of seed movement of which the daily bathing behavior of birds is, in my opinion, the most important, followed by the other daily activities of specific birds, and then by nesting activities. The bathing habits of most forest birds are such that almost any species could carry dwarf mistletoe seeds to uninfected trees. However, with respect to other daily activities I found 13 species whose frequency of occurrence implicates a significant role. The nesting habits of birds are of potential important because of the large number of species which could carry viable dwarf mistletoe seeds back to younger portions of host trees. I have observed no cases where birds have eaten or voided viable seeds.

The important question remains unanswered. What is the quantity of new infections that occur as a result of avian activity? The answer will not be easy to obtain. There are, though, several recommendations that may assist the researcher. Because bird bathing and preening habits are gene- 
rally obvious, it would be possible to inspect perches used during the bathing process for seeds of dwarf mistletoe. I attempted to reach such perches several times but, lacking proper equipment, failed. Additionally, the birds themselves could be killed and examined for the presence of seeds. A more thorough examination of nests would more precisely determine the importance of nesting habits with respect to the spread of dwarf mistletoe. On the other hand the daily habits of the 13 species discussed in the body of this text do not lend themselves to quantitative techniques. I know of no realistic methods of measuring their influence.

The economic significance of dwarf mistletoe damage to the multi-million dollar industry is extremely high. It is apparent to this author that the scope of the avian influence on the spread of this parasite should be more precisely documented. 


\section{LITERATURE CITED}

Dorst, J. 1962. The migrations of birds. Houghton Mifflin Co., Boston, Mass. 476pp.

Dyson, J. 1969. The world of ice. A. A. Knopf, New York. $292 \mathrm{pp}$.

Gabrielson, I., and S. Jewett. 1940. Birds of the Pacific Northwest. Dover Pub., New York. 650pp.

Gerber, C. and J. Cotte. 1908. Observations biologiques sur Arceuthobium juniperorum. Bull. Soc. France, $56: 4 \overline{34-435}$.

Graham, D. 1967. A training aid on dwarfmistletoe and its control. U. S. Dep. Agr. Tech. Bull. Forest Service, $6 \mathrm{PO}$. $15 \mathrm{pp}$.

Hawksworth, F. 1961. Dwarf mistletoe of Ponderosa Pine in the Southwest. U. S. Dep. Agr. Tech. Bull. 1246. $112 \mathrm{pp}$.

, F., and D. Wiens. 1972. Biology and classification of dwarf mistletoes (Arceuthobium). U. S. Dep. Agr. Handbook 401. $234 \mathrm{pp}$.

Kuijt, J. 1969. The biology of parasitic flowering plants. Univ. of Calif. Press, Berkeley, Calif. 246pp.

Meehan, T. 1882. The mistletoe. Bot. Gaz. 7:21-23.

Marshal1, J. 1957. Birds of the pine-oak woodland in Southern Arizona and adjacent Mexico. Pac. Coast Avifauna. $32: 125 \mathrm{pp}$.

Pecora, W., and A. Gerloch, and W. Overstreet. 1970 . National atlas of the United States of America. U. S. Dep. Interior, Wash., D. C. $416 \mathrm{pp}$.

Peterson, R. 1941. A field guide to western birds. Houghton Mifflin Co., Boston, Mass. $240 \mathrm{pp}$.

Ridley, H. 1930. The dispersal of plants throughout the world. L. Reeve \& Co., Ltd. Kent, England. $744 \mathrm{pp}$.

Robbins, C., and B. Bruun and H. Zim. 1966. Birds of 


\section{LITERATURE CITED (Continued)}

Golden Press, New York, 340pp.

Scharpf, J. 1964. Dwarf mistletoe on true firs in California. U. S. Dep. Agr. Forest Ser. Forest Pest Leaflet $89,1-7$.

Smith, R. 1973. Factors affecting dispersal of mistletoe seeds from an overstory Western Hemlock tree. N. W. Sci., 47 (1) 9-19.

Stewart, J. and K. Shea. 1970. Forest diseases of the Pacific Northwest. U. S. Dep. Agr. Forest Ser., 6 PO No. 999-261, 14pp.

Turrill W. 1920. Arceuthobium oxycedri and its distribution. Kew Bul1. Vol. 8, 264-268.

Wagner, G. 1968. Mistletoe ala carge. Nat. Wildlife. $6(3), 39 \mathrm{p}$.

Weir, J. 1916a. Larch mistletoe: some economic considerations of its injurious effects. U. S. Dep. Agr. Bull. $317,18-25$.

, J. 1916b. Mistletoe injury to conifers in the Northwest. U. S. Dep. Agr. Bull. 360, 28-37.

Wetmore, A. 1964. Song and garden birds of North America. Nat. Geo. Soc. Wash., D. C. $400 \mathrm{pp}$.

Wicker, E. 1969. Susceptibility of coastal form and Central Montana Douglas fir. Plant Dis. Rep. 53:311313 .

van der PijP, L. 1969. Principles of dispersal in higher plants. Springer-Verlag, New York. $154 \mathrm{pp}$.

von Schrenk, H. 1900. Notes on Arceuthobium pusillum. Rhodora, vol. II, $1-5$.

Zwinger, A. 1970. Beyond the aspen grove. Random House, New York. $368 \mathrm{pp}$. 